\title{
LAW IN TIMES OF THE PANDEMIC
}

\begin{abstract}
The essay tries to show that the legal response to a new threat, such as an unknown disease, is an outcome of many factors, including social attitudes and public sentiment. This is demonstrated by the example of regulations adopted in the $19^{\text {th }}$ century during the cholera epidemic. Similarly, restrictions are now being introduced, modified or mitigated not only under the influence of the threat itself (only partially known), but also of economic factors and social moods. Strengthening the executive branch and increasing the role of legal acts issued by this branch is a common phenomenon in the present situation. By itself, it does not threaten the rule of law yet and enables a quick reaction to a changing situation. However, excessively oppressive restrictions, in some way reversing the modern paradigm of thinking about individual rights, could be such a threat.

Keywords: pandemic, law, individual rights, legislation.
\end{abstract}

\section{PRAWO W CZASACH PANDEMII}

Streszczenie. Niniejszy esej pokazuje, że reakcja prawna na nowe zagrożenie, takie jak nieznana choroba, jest wypadkową wielu czynników, w tym postaw i nastrojów społecznych. Pokazuje to przykład regulacji przyjmowanych w XIX wieku w trakcie epidemii cholery. Podobnie obecnie ograniczenia są wprowadzane, modyfikowane czy łagodzone nie tylko pod wpływem samego zagrożenia (poznanego jedynie częściowo), ale także czynników gospodarczych oraz nastrojów społecznych. Wzmocnienie władzy wykonawczej i zwiększenie roli aktów prawnych wydawanych przez tę władzę jest zjawiskiem powszechnym w obecnej sytuacji. Samo w sobie nie zagraża jeszcze rządom prawa, a umożliwia szybką reakcję na zmieniającą się sytuację. Zagrożeniem takim mogą być jednak restrykcje nadmiernie opresyjne, odwracające w pewien sposób nowoczesny paradygmat myślenia o prawach jednostki.

Słowa kluczowe: pandemia, prawo, prawa jednostki, prawodawstwo.

\section{INTRODUCTION}

Legislation - as Hegel's "Minerva's owl"1 - is always somewhat "late", it is secondary to social phenomena, that are to be regulated by it. Regulations created "in advance", before the occurrence of a particular phenomenon,

*Angelus Silesius University of Applied Sciences in Wałbrzych, Institute of Socio-Legal Studies; pszymaniec@poczta.onet.pl

1 "The owl of Minerva spreads its wings only with the falling of the dusk" (Hegel 1976, 13). 
most often turn out to be insufficient or even inappropriate. This aspect of legal regulation is apparent in case of norms intended to outdistance technical progress by defining the legal consequences of using technologies that are not yet in common use. The same feature is also visible in case of legal response to new, hitherto unknown safety threats, such as pandemics of previously unknown diseases.

This work is devoted to the changes in of law and legislation that took place during the current COVID-19 pandemic. In a short essay like this one it is impossible to cover all relevant legal problems related to such a complex phenomenon. Therefore I will limit myself to highlight some features of the emergency legislation implemented that I consider essential. The current pandemic, with its social and legal consequences, is not substantially different from those occurred in the past. Perhaps the only essential difference distinguishing it from previous similar events is the speed at which the threat spreads. In previous major epidemics, the law has also been used to try to gain control over the situation. Comparing the past regulations with the current ones is difficult, since the former were implemented in different social and economic conditions than ours. But while medical knowledge has changed, social responses to new threats remain similar to some extent. To shed light on this, I will look at one example of a pandemic that took place on the brink of modernity, when economic relations were already capitalist and mass society was emerging: cholera epidemic in Europe in the 1830 s. I chose this example, rather than, for instance, the more frequently reported Spanish flu pandemic, because, much like in the current pandemic crisis, public administration of European states intervened to capture and govern a health crisis through strong and articulated legal provisions. In Prussia, for example, the state administration was particularly scrupulous in documenting the course of the epidemic, so that one can follow the changing situation, the activities of the administration, and the evolving legal regulations in response to this situation almost day after day.

\section{THE LAW AND THE CHOLERA EPIDEMIC}

Six cholera pandemics took place in the $19^{\text {th }}$ century. The first one $(1817-$ 1824) passed through India, Southeast Asia, the Middle East, East Africa and reached the shores of the Mediterranean Sea. The second pandemic (1826-1837/1838) involved manly Europe in the hot time of the revolutionary movements and the November Uprising in the Kingdom of Poland. Then it reached North America. Only in France alone, it cost about 100,000 lives (out of a population of 33.5 million). Among the European victims were some prominent figures, just to mention Grand Duke Konstantin Pavlovich of Russia and his wife, Prussian military general Carl von Clausewitz, the 
commander-in-chief of the Russian army Ivan Dybich, and the philosopher G.W.F. Hegel. Cholera appeared in Russia in 1829, then it was recorded in Moscow in September 1830. In February of the following year it reached St. Petersburg and the Polish lands ${ }^{2}$ engulfed by the uprising, and from there it spread all over Europe. Almost everywhere, it was preceded by panic among the population, fueled by the press. Particularly interesting is the reaction of the Prussian authorities. The first cases of cholera in the territory of Prussia were recorded in May 1831. The administration issued daily bulletins on the spread of the disease. At that time, a number of order regulations were introduced for the period of the epidemic. Poznan (Posen) and Gdańsk (Danzig), the two cities where the disease was recorded for the first time, were cordoned off. The borders were closed and people coming from Russia were quarantined. Traveling was possible only for those who had special travel documents. Offices, schools and theaters were closed, only churches remained open. Freedom of speech was also restricted, since it was forbidden to proclaim that cholera was not contagious. The regulations, initially followed scrupulously, concerned specific hygienic issues (disinfection of various objects with calcium chloride) and the treatment of the sick people and the corpses of the deceased (houses where the disease had occurred were marked). The adopted measures were very expensive, and their economic burden was primarily on cities and communes (some even had to go into debt). Panic broke out rapidly among the population. Riots of the poor, fueled also by rumors that the disease was invented by the rich in collusion with doctors, the riots of the lower classes were the reaction to food price speculation. Moreover, the epidemic was progressing more slowly than originally thought. Therefore, it became clear that the adopted restrictions would not last long. When cholera appeared in Berlin in August 1831, they were already abolished. ${ }^{3}$

The state of medical knowledge at the time was another factor influencing the legislation. The etiology of cholera was not known until the discoveries of Robert Koch. Two opposing theories were developed among medical doctors. According to the first, cholera was contagious and transmitted by touch, while the second pointed out thar the disease was to be caused by "miasma", i.e. a harmful, but not contagious factor occurring in the environment that could be

${ }^{2}$ According to official data, widely regarded by contemporary historians as greatly underestimated, 22,718 inhabitants of the Kingdom of Poland of 3 million 900 thousand suffered from cholera. 13,105 people died. It is estimated that 40,000 could be infected, half of which died. Cf. Olkowski 1968, 533. About 10\% of the population died in the towns of East Prussia, where the epidemic appeared. Cf. Olkowski 1968, 559.

${ }^{3}$ Initially, the residents of the house where cholera appeared were quarantined for 20 days. Over time, the number of quarantine days was reduced to 10 and then to 5. Cf. Becker 1832, 51. The change in regulation was driven by economic factors. It was difficult to keep the "working poor" in quarantine for a longer period of time, because they had to earn a living. 
activated under favorable conditions. While the first theory was dominant in the first period of the epidemic, the second theory gained priority and it was used as a justification for departing from the restrictions, not only in Prussia, but also in Russia and Italy, even though the epidemic was still ongoing. ${ }^{4}$

\section{3. "RISK STAGING" AND THE LAW}

The example presented here shows a certain - and, in my view, inevitable - inadequacy of the adopted regulations to a phenomenon that is known only fragmentarily at a given moment. Moreover, it makes manifest how not only medical factors, but also social expectations and economic conditions determine when restrictions are introduced and when they are relaxed or even abandoned. Ulrich Beck in elaborating his theory of risk society (Risikogesellschaft) introduced a term that is particularly relevant for a correct critical consideration of the way in which decision during emergencies are taken: staging of risk. By this notion, Beck understood the social processes determining to what extent a given event of which we do not possess an adequate knowledge, is and should be considered a threat and how to respond to it using different means, including legal provisions. ${ }^{6}$ From his perspective all the legal and legislative decisions concerning a new and hitherto unknown threat are based on a kind of fiction framed during the "staging of risk" process. ${ }^{7}$ At the same time, according to Beck, "staging

${ }^{4}$ For the details on fighting the cholera in Prussia, cf. Markiewicz 1994, 79-86; Olkowski 1968, 533-570; Ross 2015, 59-195; Stamm-Kuhlmann 1989, 176-189.

${ }^{5}$ The first version of this concept was presented after the Chernobyl disaster, but later the scholar added important new factors such as globalization and international terrorism.

${ }^{6}$ Cf. Beck 1992; Beck 2008. For the discussion about Beck's theory, cf. Stankiewicz 2008, $117-132$

${ }^{7}$ In his classic, albeit highly controversial theory of state of exception, Carl Schmitt argued that modern concept of the state of emergency is based on legal fiction, since the use of emergency measures prescribed by the law (all the legal machinery of the state of exception) is based on the declaration of state's authorities, rather than on the factual state. Schmitt traced the origins of French doctrine of 'fictitious state of siege' (état de siège fictif). As he pointed out, the institution of "state of siege" as developed during the French Revolution (1791) was of military character. The legal institution underwent, however, transformation during the Spring of Nations when the replacement of actual state of siege by a mere declaration (decision) of state powers took place. The fictitiousness of the institution of state of exception was even deepened by the French of 1878. Cf. Schmitt 2014, 127-161. The fictitious nature of the state of exception has been further emphasized by contemporary Italian philosopher Giorgio Agamben. As Gian Giacomo Fusco nicely summarized Agamben's point of view: "Given its dependence on the decision of a sovereign authority, the state of exception becomes an effective instrument to be turned on or off at will, even when a threat has not yet materialised or its being a menace is not explicitly evident": Fusco 2021, 23. Cf. Agamben 2005, 1-31. It is quite evident that during current pandemic several states implemented harsh measures of the state of emergency declared de iure or only de facto 
of risk" is not a purposeful fraud, but an imperfect tool used by society to try to avoid future catastrophes (Egner 2011, 21). In this process not only scientists, but also politicians, business entities, and civil society institutions are involved. In my view, Beck's concept could be useful to understand current changes in crisis legislation, including subsequent lockdowns and relaxations. Beck's concept shows well that the legal regulation of threats is not only related to the nature of the threats themselves (which are often only partially known to us), but is the result of a wider social process in which not only experts, but also politicians and social expectations and moods play an important role. A good example is the short-term loosening of restrictions in Poland in the second half of February and at the beginning of March 2021, undoubtedly resulting from the mood in Polish society at that time.

In the current pandemic, the authorities' decisions are made under conditions of limited access to information. The full knowledge of the COVID-19 disease and the factors affecting its spread and course in specific segments of population will probably have to wait a few more years. Inevitably, these decisions may turn out to be suboptimal or even wrong afterwards, but it is difficult to afford not to take any action. Moreover, in this case there is a tendency to copy the anti-crisis policy model that is already being implemented in neighboring states. It may be regarded as the least risky one or at least allowing for the "division" of responsibility, in the eyes of society, between all governments implementing a given policy model. I also think that during an epidemic, even multiple changes to legal acts issued by the government is something inevitable. Legal regulations must follow the dynamics of the very phenomenon. Decisions considered to be justified today may soon turn out to be insufficient or excessively restrictive. The possibility of making quick changes in these regulations characterizes the appropriate crisis management mechanisms.

\section{STRENGTHENING THE EXECUTIVE POWER}

Almost everywhere (except only a few states, e.g. Sweden which, by the way, changed a bit its policy towards the epidemic during the so-called the second wave in autumn 2020), the COVID-19 pandemic has strengthened the executive branch. This is also visible in Poland: the Act of December 5, 2008 on the prevention and combating of infections and infectious diseases in humans, as amended in March 2020 (consolidated text: Journal of Laws of 2020, 1845 as

even before the threat actually occured. In my view, Beck's theory adds another dimension to the considerations on the factiousness of the institution of the state of emergency: since in case of new threats the actual risk cannot be determined with certainty (the risk itself is "staged"), the state authorities follow their own expectations and social moods while implementing certain legal measures and tool. 
amended), authorized the Council of Ministers in Articles 46a-46b to define certain restrictions by a regulation, including "temporary limitation of certain range of activity of entrepreneurs", "temporary limitation of the use of premises or land" or "ordering a specific way of travelling" (Article 46b points 2, 8, 12). There is neither a maximum period for which these restrictions may be in place, nor the procedure for assessing the legitimacy or adequacy of these restrictions by the legislature. ${ }^{8}$

The government's legislative activity under statutory authorization is particularly visible in France. ${ }^{9}$ Pursuant to the Constitution of the Fifth Republic of 1958, the Council of Ministers has the power to issue decrees and ordinances. On March 22, 2020, ${ }^{10}$ the French Parliament passed a law giving the government extended powers to issue decrees for two months during the "state of health emergency" (l'état d'urgence sanitaire) concerning, inter alia, limiting the movement of people and ordering the requisition of goods and services. Legal

${ }^{8}$ Theorists writing on states of emergency in modern democracies pointed out that modern crisis government must be strong and at the same time limited. Such a position is strongly emphasized in the classic study by Clinton Rossiter (1917-1970); cf. Rossiter 1948, 5-7. Rossiter also noted that the government was reluctant to give up powers taken over during the state of exception, and that such a state could be extended indefinitely. The constitutionalization of states of emergency was to be an obvious remedy for this threat. However, in states that are considered to be stable democracies, another model, called legislative model, has developed as well. In this model, implemented inter alia in Germany, Italy, Spain, United Kingdom and the U.S., "emergency powers are provided in the ordinary legislative process": Farejohn, Pasquino 2004, 217. Post-communist states has usually chosen a model based on the constitutional regulation of the states of exception. The current epidemic has to some extent called into question the approach to emergencies so far. In Poland, the epidemic management has been carried out under two legal regimes that are not regulated in the constitution, namely the state of epidemic threat and state of epidemic. Both are regulated by the Act of December 5, 2008 on the prevention and combating of infections and infectious diseases in humans. If in Poland the management of a pandemic situation was conducted into the corset of a constitutional extraordinary measures, it would not be possible to limit some constitutional rights and freedoms. For instance, the freedom of conscience and religion (Article 53 of the Polish Constitution of April 2, 1997) could not be limited at all, because in the case of a state of emergency and martial law, this freedom was included in the catalog of those rights and freedoms that cannot be limited (Article 233 (1) of the Constitution). Moreover, this freedom was not listed among the rights that may be subject to restrictions during a state of natural disaster (Article 233 (3) of the Constitution).

${ }^{9}$ Italy could serve as another example. Since the turbulent era of 1970s and 1980s (anni di piombo), governmental law-decrees are widely used in situation of emergency. The normative basis of such a practice is Article 77 of the Constitution of the Italian Republic (1947), which has been interpreted in such a way to enable the government to temporary measures valid for 60 days "in case of necessity and urgency." Cf. Fusco 2021, 25-26 (footnote).

${ }^{10}$ Loi n ${ }^{\circ} 2020-290$ du 23 mars 2020 d'urgence pour faire face à l'épidémie de COVID-19, https://www.legifrance.gouv.fr/affichTexte.do?cidTexte=JORFTEXT000041746313\&categorieLi en=id. Cf. C. Desfontaines, "COVID-19: Confinement - Measures taken by the Government and applicable penalties," https://www.soulier-avocats.com/en/covid-19-confinement-measures-taken-by-the-government-and-applicable-sanctions/ [Accessed: 19 February 2021]. 
acts issued on this basis enter various areas of law, including the sphere of civil law contracts, inter alia, by postponing payment terms for specific services (Grynbaum 2020). The Act of May 11 extended the "state of health emergency", and thus also the powers of the government, for another two months. The law of July $11,2020^{11}$ repealed these regulations, but at the same time introduced a "régime transitoire" under which the government continues to have the power to adopt emergency measures. The regime, initially expected to last until the end of October, was extended by the law from October 1 to April 1, 2021. Moreover, the decree of October 14, 2020, ${ }^{12}$ i.e. an act of the executive power, reintroduced the state of health emergency, which was extended by the Act of November 14, $2020^{13}$ until February 16, 2021. The introduced catalog of situations in which it is possible to leave the place of residence, and the restrictions on movement by residents can be changed by the executive authority. Government legislation in itself does not yet pose a threat to the rule of law, provided that it is maintained within the constitutional.

\section{INDIVIDUAL RIGHTS}

Greater or lesser restrictions on human or civil rights and freedoms accompany the current epidemic. They cover a wide range of norm, from wide restrictions on freedom of movement, through far-reaching limitation of freedom of assembly and freedom to manifest religion or belief, to interference in economic freedoms. Even in states with a high standard of human rights, it happens that unjustified restrictions go beyond what is necessary under the present conditions. I will give just one example my field of interest. In Germany, following the recommendations of the federal government, the majority of federal states (Länder) introduced a general ban on religious services in April 2020, granting no exceptions. A Muslim religious association from Lower Saxony appealed against the provision of $\S 1$ (clause 5) of the federal state's regulation on protection against new coronavirus infections of April 17, 2020, prohibiting "meetings in churches, mosques, synagogues and meetings of other religious communities." The association wanted to organize prayers every Friday for the remainder of Ramadan, while maintaining a strict sanitary regime, i.e. 1.5 meters between prayers and a maximum number of 24 people during one prayer in a mosque that

${ }^{11}$ Loi n ${ }^{\circ} 2020-856$ du 9 juillet 2020 organisant la sortie de l'état d'urgence sanitaire, https:// www.legifrance.gouv.fr/jorf/id/JORFTEXT000042101318/ [Accessed: 19 February 2021].

${ }^{12}$ Décret n ${ }^{\circ} 2020-1257$ du 14 octobre 2020 déclarant l'état d'urgence sanitaire, https://www. legifrance.gouv.fr/jorf/id/JORFTEXT000042424377 [Accessed: 19 February 2021].

${ }^{13}$ Loi n ${ }^{\circ} 2020-1379$ du 14 novembre 2020 autorisant la prorogation de l'état d'urgence sanitaire et portant diverses mesures de gestion de la crise sanitaire, https://www.legifrance.gouv.fr/jorf/ id/JORFTEXT000042520662?r=xlhRIpB5A0 [Accessed: 19 February 2021]. 
could accommodate 300 worshipers. In the judgment of April 29, 2020, the Federal Constitutional Court in Karlsruhe declared the prohibition unconstitutional, ruling its suspension, because the challenged regulation did not provide for exceptions enabling collective worship in individual cases. ${ }^{14}$ Such a decision is, on the one hand something that allows us to look at the judiciary with optimism, and on the other hand it is a clear signal of the excesses of certain emergency laws implemented during the pandemic. ${ }^{15}$

${ }^{14}$ Bundesverfassungsgericht, Beschluss der 2. Kammer des Ersten Senats vom 29. April 2020, https://www.bundesverfassungsgericht.de/SharedDocs/Entscheidungen/DE/2020/04/ qk20200429_1bvq004420.html [Accessed: 19 February 2021].

${ }^{15}$ In the second phase of the epidemic, in the fall of 2020, restrictions on the freedom of religion were also introduced. Against the background of the regulations introduced at that time a case of Belgium it is particularly interesting. The regulation of the Minister of the Interior of October 28 establishing emergency measures to limit the spread of the COVID-19 coronavirus introduced the principle of social distancing and a maximum number of 40 participants during the collective worship (28 Octobre 2020. - Arrêté ministériel portant des mesures d'urgence pour limiter la propagation du coronavirus COVID-19, 78132, „Moniteur Belge” 2020, No. 304). These provision were quite moderate. However, just two days later the regulation was changed (1 Novembre 2020. - Arrêté ministériel modifiant l'arrêté ministériel du 28 octobre 2020 portant des mesures d'urgence pour limiter la propagation du coronavirus COVID-19). After the amendment, fifteen persons were allowed to participate in funerals and cremations (children up to 12 were not included in this number), whole in case of weddings only spouses, their two witnesses and the registrar or minister of religion were legitimate to take part, regardless whether the wedding was religious or secular (Article 15 para. 3 and 4). The amended article 17 prohibited the exercise of collective worship and "the collective exercise of collective exercise of non-confessional moral assistance (l'assistance morale non confessionnelle) and activities in within the framework of the non-confessional association (association philosophique-non-confessionnelle)", with the exception of only worship or non-confessional moral assistance during weddings, funerals and cremations, as well as services or non-competitive moral aid recorded for dissemination through all possible channels, while the recording was to take place without the participation of the audience, and up to 10 people could participate in its realization, including technical staff. The above-mentioned regulations were appealed against on December 4, 2020 to the Council of State (Raad van State) by the Congregation of Yetev Lev Dsatmar Antwerp, being an organization of Judaic character, registered as a company under British law, and five private individuals. According to the applicants, the collective religious freedom of adherents of Judaism was almost completely suspended. It was also emphasized that Judaism requires the presence of ten men (minyan) for certain prayers and religious rites, including weddings. Thus, due to restrictions, no Jewish wedding could be properly performed. While the aim of the regulation was justified, disproportionate means were used. $\mathrm{n}$ its decision, the Council of State gave the government five days to replace the challenged provisions of Article 15 and Article 17 of the regulation with new regulations that will not disproportionately restrict the collective exercise of religious worship. Moreover, according to the Council, it was necessary for the new regulations to be drafted in consultation with representatives of religious communities and nonconfessional philosophical associations (Raad van State, Afdeling Bestuursrechtspraak Xe Kamer, Arrest nr. 249.177 van 8 december 2020 in de ak A. 232.384 / X-17.848, point 25). As a result of the judgment, on December 11, 2020, the regulation was amended. Article 17 was repealed, and in article 15 para 3 was amended in order to allow the group up to 15 persons to participate collective worship and the activities of worldview associations, as well as weddings, cremations and 
But what is more, the restrictions introduced during the pandemic crisis all over Europe have been often far from precise, so that they lead to almost banal considerations that is not always clear where a given prohibition begins and ends. The danger of imprecise norms is that, in extreme cases, they may lead to a reversal of the legal principle emphasizing that what is not explicitly forbidden by law is permitted. This principle was introduced by Montesquieu in his considerations about liberty in a "moderate" system. It is meaningful here that the French jurist saw England as the most perfect existing example of such a system and the English system provided inspiration to develop the concept of separation of powers. ${ }^{16}$ Paradigmatic in this regard is the ministerial ordinance adopted in England and Wales on March 26, 2020 (announced three days in advance) ${ }^{17}$ stating (paragraph 6) that no one may leave the place of living without a "reasonable excuse", while very casuistic situations regarded as reasonable excuses were listed. For instance, a reasonable excuse was to go "to obtain basic necessities, including food and medical supplies for those in the same household (including any pets or animals in the household)." Only two-person assemblies were allowed, and only a few exceptions were introduced from this provision, e.g. funeral attendance. Similar regulations were introduced in other parts of the United Kingdom. The public was also told that one form of physical exercises, such as running or cycling, was acceptable per day. These regulations were, I would admit, the most far-reaching restrictions on the rights of the individual introduced on the Islands since the Glorious Revolution of 1688. Such restrictions reversed the Montesquieuean paradigm of understanding the role of statutory law in a constructional state. The Western modern state - in each of its classic models, developed in the nineteenth century, i.e. the German, French, British or American model - was not to be a monster like the mythological Argus Panoptes using his hundred eyes to discipline everyone. A shift of paradigm mentioned here means a complete change in the role of the state. During the current pandemic a dangerous precedent for the perception of the role of law in a democratic state has been introduced. This precedent may be used in the future to curtail the fundamental rights and freedoms of an individual in case of other threats, even much smaller than the SARS-COV-2 virus.

funerals (11 Decembre 2020. - Arrêté ministériel modifiant l'arrêté ministériel du 28 octobre 2020 portant des mesures d'urgence pour limiter la propagation du coronavirus COVID-19, art. 1). This case shows, similarly to the mentioned German judgment, the functioning of an effective mechanism of constitutional review of limitations, leading, in a very short period of time, to specific changes to legal provisions.

${ }^{16}$ Cf. Montesquieu 17811-8. Cf. Szymaniec 2013, 93. Montesquieuean doctrine of liberty was developed and broadened by liberal thinkers like Benjamin Constant (who used the term "liberty of the moderns"). Cf. Constant 1988, 308-328; Lumowa 2010, 389-414.

17 “"The Health Protection (Coronavirus, Restrictions) (England) Regulations 2020", Statutory Instruments 2020, no. 350 . 


\section{CONCLUSIONS}

In this essay, I wanted to show that the legal response to a new threat, such as an unknown disease, is an outcome of many factors, including social attitudes and public sentiment. This is demonstrated by the example of regulations adopted in the $19^{\text {th }}$ century during the cholera epidemic. Similarly, restrictions are now being introduced, modified or mitigated not only under the influence of the threat itself (only partially known), but also of economic factors and social moods. Sometimes the hidden purpose of certain restrictions is to influence these sentiments. Strengthening the executive branch and increasing the role of legal acts issued by this branch is a common phenomenon in the present situation. By itself, it does not threaten the rule of law yet and enables a quick reaction to a changing situation. However, excessively oppressive restrictions, in some way reversing the modern paradigm of thinking about individual rights, could be such a threat. Shifting from a descriptive to a normative perspective, I would emphasize that perhaps there is no better way to protect individual rights than to take the principle of proportionality seriously. This principle, derived from Aristotelian concept of the "golden mean" in the most general terms is common in Western legal culture and consists in resolving conflicts of different principles, reasons or values not by eliminating one of them, but by balancing them (Łętowska 2015, 15-22). ${ }^{18}$ In the Polish legal system, this principle is in Article $31 \mathrm{sec} .3$ of the Constitution of the Republic of Poland of April 2, 1997. Public health is mentioned in this provision as one of the values justifying the limitation on exercise of individual rights when it is necessary in a democratic state.

\section{BIBLIOGRAPHY}

Agamben, Giorgio. 2005. State of Exception. Translated by Kevin Attell. Chicago-London: Chicago University Press. https://doi.org/10.7208/chicago/9780226009261.001.0001

Alexy, Robert. 2017. "Proportionality and rationality." In Proportionality. New Frontiers. New Challenges. 13-29. Edited by Vicki C. Jackson, Mark Tushnet. Cambridge: Cambridge University Press. https://doi.org/10.1017/9781316691724.002

Barak, Aharon. 2012. Proportionality: Constitutional Rights and their Limitations. Cambridge: Cambridge University Press. https://doi.org/10.1017/CBO9781139035293

Beck, Ulrich. 1992. Risk Society: Towards a New Modernity. London: Sage.

Beck, Ulrich. 2008. World Risk Society. Cambridge: Polity Press.

Becker, Ferdinand Wilhelm. 1832. Letters on the Cholera in Prussia: Letter I. To John Thomson. London: John Murray.

Constant, Benjamin. 1988. "The Liberty of the Ancients Compared with that of the Moderns." In Political Writings. 308-328. Translated by Biancamaria Fontana. Cambridge: Cambridge University Press.

${ }^{18}$ Cf. Barak 2012; Alexy 2017, 13-29. 
Egner, Heike. 2011. "Enforced Cosmopolitanization and the Staging of Risks." In Revisiting Risk Society. A Conversation with Ulrich Beck. 19-21. Munich: Rachel Carson Center for Environment and Society.

Farejohn, John Pasquino Pasquino. 2004. "The law of the exception: A typology of emergency powers." International Journal of Constitutional Law 2(2): 210-239. https://doi.org/10.1093/ icon/2.2.210

Fusco, Gian Giacomo. 2021. "Exception, fiction, performativity." In States of Exception: Law, History, Theory. 15-33. Edited by Cosmin Cercel, Gian Giacomo Fusco, Simon Lavis. Abington-New York: Routlege. https://doi.org/10.4324/9780429022296-1

Grynbaum, Luc. 2020. "COVID-19 French health emergency orders and adaptation of contracts." De Gaulle Fleurance \& Associés, March 27, 2020. https://www.degaullefleurance.com/ en/ordonnances-etat-durgence-sanitaire-covid-19-et-adaptation-des-contrats/ [Accessed: 19 February 2021].

Hegel, Georg Wilhelm Friedrich. 1976. Hegel's Philosophy of Right. Translated by T.M. Knox. London-Oxford-New York: Oxford University Press.

Lumowa, Valentino. 2010. "Benjamin Constant on Modern Freedoms: Political Liberty and the Role of a Representative System." Ethical Perspectives 17(3): 389-414.

Łętowska, Ewa. 2015. "Wprowadzenie do problematyki proporcjonalności." In Zasada proporcjonalności a ochrona praw podstawowych w państwach Europy. [The Principle of Proportionality and the Protection of the Fundamental Rights in the European States]. 15-22. Edited by Piotr Szymaniec. Wałbrzych: Wydawnictwo PWSZ AS.

Markiewicz, Barbara. 1994. Żywe obrazy. O ksztaltowaniu pojęć poprzez ich przedstawienie. Warszawa: Wydawnictwo Instytutu Filozofii i Socjologii PAN.

Montesquieu (Secondat, Charles de). 1781. A view of the English constitution. By the late Baron de Montesquieu. Being a translation of the sixth chapter of the eleventh book of his celebrated treatise L'Esprit des Loix. Translated by Francis Masères. London: W. White and H. Payne.

Olkowski, Zbigniew. 1968. "Epidemia cholery azjatyckiej w Prusach Wschodnich w latach 18311832." Komunikaty Mazursko-Warmińskie 4: 531-572.

Ross, Richard S. III. 2015. Contagion in Prussia, 1831: The Cholera Epidemic and the Threat of the Polish Uprising. Jefferson, North Carolina: McFarland \& Company.

Rossiter, Clinton L. 1948. Constitutional Dictatorship. Princeton: Princeton University Press.

Schmitt, Carl. 2014. Dictatorship. From the Origin of the Modern Concept of Sovereignty to the Proletarian Class Struggle. Translated by Michael Hoelzl and Graham Ward. Cambridge: Polity Press.

Stamm-Kuhlmann, Thomas. 1989. "Die Cholera von 1831. Herausforderungen an Wissenschaft und staatliche Verwaltung." Sudhoffs Archiv 73(2): 176-189.

Stankiewicz, Piotr. 2008. "W świecie ryzyka. Niekończąca się opowieść Ulricha Becka.” Studia Socjologiczne 3(190): 117-132.

Szymaniec, Piotr. 2013. Republikanizm dla społeczeństwa handlowego. Myśl polityczno-prawna Adama Fergusona. Wałbrzych: Wydawnictwo PWSZ AS.

\section{Legal Acts}

Act of December 5, 2008 on the prevention and combating of infections and infectious diseases in humans (Poland). Consolidated text: Journal of Laws of 2020, 1845 as amended.

Constitution of the Republic of Poland of April 2, 1997, Journal of Laws, 1997, No. 78, item 483 as amended.

Décret $n^{\circ} 2020-1257$ du 14 octobre 2020 déclarant l'état d'urgence sanitaire, https://www.legifrance. gouv.fr/jorf/id/JORFTEXT000042424377 [Accessed: 19 February 2021]. 
Loi n 2020-290 du 23 mars 2020 d'urgence pour faire face à l'épidémie de COVID-19, https:// www.legifrance.gouv.fr/affichTexte.do?cidTexte=JORFTEXT000041746313\&categorieLien =id. Cf. C. Desfontaines, "COVID-19: Confinement - Measures taken by the Government and applicable penalties." https://www.soulier-avocats.com/en/covid-19-confinement-measurestaken-by-the-government-and-applicable-sanctions/ [Accessed: 19 February 2021].

Loi $\mathrm{n}^{\circ}$ 2020-856 du 9 juillet 2020 organisant la sortie de l'état d'urgence sanitaire. https://www. legifrance.gouv.fr/jorf/id/JORFTEXT000042101318/ [Accessed: 19 February 2021].

Loi $\mathrm{n}^{\circ}$ 2020-1379 du 14 novembre 2020 autorisant la prorogation de l'état d'urgence sanitaire et portant diverses mesures de gestion de la crise sanitaire. https://www.legifrance.gouv.fr/jorf/ id/JORFTEXT000042520662?r=xlhRIpB5A0 [Accessed: 19 February 2021].

28 Octobre 2020. - Arrêté ministériel portant des mesures d'urgence pour limiter la propagation du coronavirus COVID-19, p. 78132, „Monituer Belge” 2020, No. 304.

1 Novembre 2020. - Arrêté ministériel modifiant l'arrêté ministériel du 28 octobre 2020 portant des mesures d'urgence pour limiter la propagation du coronavirus COVID-19.

11 Decembre 2020. - Arrêté ministériel modifiant l'arrêté ministériel du 28 octobre 2020 portant des mesures d'urgence pour limiter la propagation du coronavirus COVID-19.

The Health Protection (Coronavirus, Restrictions) (England) Regulations 2020, "Statutory Instruments" 2020, no. 350. 